\title{
The Rise of Self-Defense in Gun Advertising: \\ The American Rifleman, 1918-2017
}

Paper prepared for session on "Guns and Markets"

University of Arizona Gun Studies Symposium

20 October 2017

\author{
David Yamane \\ Sebastian L. Ivory \\ Paul Yamane \\ Department of Sociology \\ Wake Forest University \\ yamaned@wfu.edu \\ 336/758-3260
}


The 2 February 1918 issue of Arms and the Man, the fortnightly official publication of the National Rifle Association of America, runs just 19 pages and includes 16 advertisements. The ads include familiar products such as bore cleaning paste, shooting gallery targets, reloading tools, and .22 caliber cartridges. Gun industry household names like DuPont, Remington, and Hoppe's sell their powders, firearms, and solvents, and books are offered for sale by Edward C. McKay of Cleveland, Ohio. On the inside front cover - prized magazine advertising real estate - a half page ad placed by The Peters Cartridge Company of Cincinnati, Ohio touts the "exclusive and superior features" of Peters shotgun shells. The ad highlights the success of W.H Heer of Guthrie, Oklahoma and Woolfolk Henderson of Lexington, Kentucky, the amateur trapshooters with the highest averages in 1917. In fact, it was the $6^{\text {th }}$ time in the past 8 years that highest amateur honors were won with Peters shells. The back cover of the issue has four advertisements, the largest of which is a half-page ad placed by Colt's Patent Firearms Mfg. Co. of Hartford, Connecticut. Drawings of soldiers carrying M1911 auto-pistols, one in a U.S. Navy uniform and one in an Army uniform, book end the ad's large font declaration of Colt Firearms to be "Ready for Duty." The smaller ad copy in the right column elaborates:

On the Battlefield - In the Preservation of Law and Order-The Protection of Home and Country - Whenever and wherever armies or individuals have to 
enforce right with might-COLT'S FIREARMS have been creating, building and maintaining a reputation for merit, efficiency and reliability that has resulted in a position of unquestioned superiority.

Completing this early example of the "militarization" of civilian gun culture, the ad concludes with the assertion: "You make no mistake when you follow the Government's example and adopt COLT'S for YOUR Firearm needs."



Examining this gun magazine 100 years later highlights some similarities and many differences. It remains the official journal of the National Rifle Association, though it was renamed The American Rifleman in 1923 and is now published monthly. It continues to have almost as many advertisements as pages, but reflecting trends in 
magazine publishing generally, it has swollen to 118 pages with 75 advertisements in the January 2017 issue. The American Rifleman continues to include ads for guns, ammunition, reloading equipment, and targets. Colt Firearms returns with its ad for the Combat Unit Rail Gun, a modern updating of its historic Government Model .45 Auto M1911 service pistol. Remington does not have an ad in this particular issue, but other brand-name gun manufacturers do, including Browning, Heckler \& Koch, Sig Sauer, Sturm, Ruger \& Co., Savage, Walther, and Smith \& Wesson.

One of the biggest changes from 1918 to 2017 , and the focus of this chapter, is in the ways companies try to motivate consumers to buy guns and related accessories. While the 1918 Colt Firearms ad includes a brief reference to "The Protection of Home," the 2017 issue is full of advertisements for products specifically designed and sold for personal protection, especially through concealed carry. In an advertisement that covers the entire back page, the M\&P Shield semi-auto pistol from Smith \& Wesson is described as "slim, concealable and powerful," making it "Comfortable to carry" and "Comfortable to shoot." Another full page ad in the same issue again shows the M\&P Shield, this time equipped with a combination laser and flashlight to assist with target acquisition. Manufactured by Crimson Trace, a pioneer in selling laser sights in the civilian marketplace, the "Laserguard Pro offers the ultimate advantage in personal protection." The ad also includes a smaller picture of the M\&P Shield in a holster specially designed to accommodate the gun with Crimson Trace's aftermarket 
light/laser combo. This reminds us that carrying even a slim and concealable handgun requires some sort of holster. Enter BUGBite Holsters. Their full page ad shows a man resting on his right knee and pulling up the left pant leg on his jeans to expose a neoprene calf sleeve, like those worn by ailing athletes, above his white sneaker and ankle sock. But this particular calf sleeve, with built-in pockets to hold a small pistol and spare ammunition magazine, is actually a "new holster concept." As the ad copy asserts: "Revolutionizing what it means to carry a firearm in comfort and concealment."

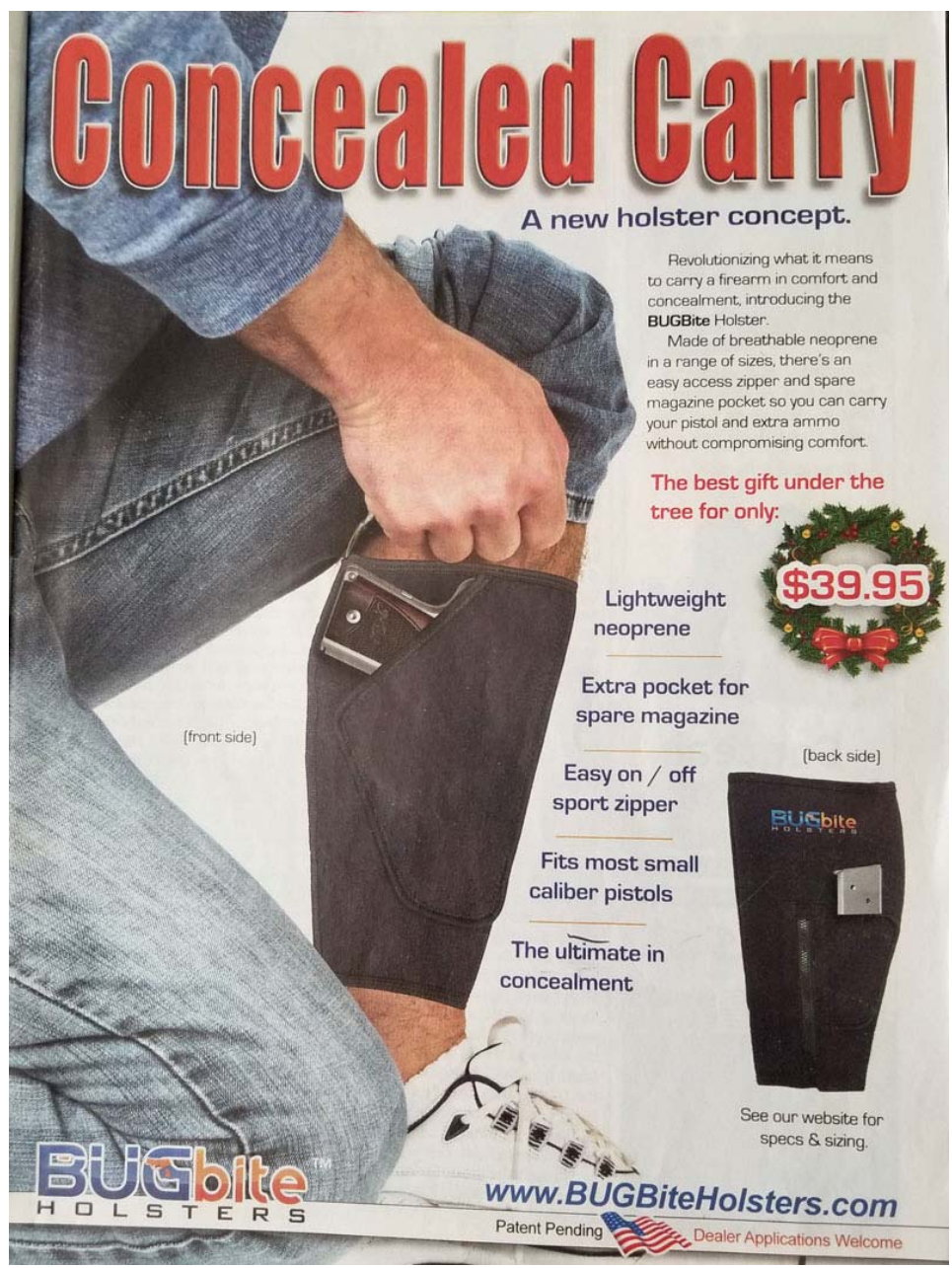


These impressionistic observations of the differences in ads placed in a 1918 issue of Arms and the Man and a 2017 issue of The American Rifleman are suggestive of broader changes taking place in American gun culture over the past century. This chapter examines these changes more systematically through a content analysis of advertisements in this magazine for every year from 1918 to 2017. We understand the changing themes in these ads as a specific measure of a change from what gun journalist Michael Bane calls Gun Culture 1.0, rooted in hunting and recreational target shooting, to Gun Culture 2.0, centering on personal protection through armed citizenship. Central to Gun Culture 2.0 is the legal carrying of concealed weapons, mostly handguns, in public by ordinary Americans.

After briefly reviewing the history of American gun culture, we discuss our analytical approach to studying gun culture through advertising and explain the specific data and methods employed here. Our analysis of this advertising data documents the pattern of decline of Gun Culture 1.0 over the past 100 years and the ongoing rise of Gun Culture 2.0. We also identify the point at which the two centers of gravity in gun culture cross paths. 


\section{A Brief History of and Approach to Studying Changes in American Gun Culture}

As others have argued at great length, guns were part of the social reality of the United States well prior to its Declaration of Independence from the British crown and its Constitutional founding. ${ }^{1}$ That the reality of guns which began at Jamestown and Plymouth Rock continues in America today confounds many critics. In 1970, two-time Pulitzer Prize-winning historian Richard Hofstadter published an influential essay in American Heritage Magazine called "America as a Gun Culture." In it he lamented the uniqueness of the United States "as the only modern industrial urban nation that persists in maintaining a gun culture." In Hofstadter's account, America's gun culture is rooted in the reality of widespread, lawful possession of firearms by a large segment of the population. One reliable estimate of gun ownership in early America found guns in 50-73 percent of male estates and 6-38 percent of female estates. These rates compare favorably to other common items listed in male estates like swords or edged weapons (14\% of inventories), Bibles (25\%), or cash (30\%). Today, at least 40 percent of American households still probably have a gun or guns in them. ${ }^{2}$

\footnotetext{
${ }^{1}$ Cramer, Clayton E, Armed America: The Remarkable Story of How And Why Guns Became As American As Apple Pie. (Nashville, TN: Thomas Nelson Inc, 2006); Craig R. Whitney, Living with Guns: A Liberal's Case for the Second Amendment (New York: Public Affairs, 2012); Adam Winkler, Gunfight: The Battle over the Right to Bear Arms in America (New York: W.W. Norton, 2011).

${ }^{2}$ James Lindgren and Justin L. Heather, "Counting Guns in Early America," William \& Mary Law Review 43:5 (2002):1777-1842, and David Yamane, "How Many Households in America Today Have Guns?" Gun Culture 2.0 Blog. Retrieved on 29 September 2017 from https:/gunculture2point0.wordpress.com/2017/02/02/how-many-households-in-america-today-haveguns/.
} 
Early on, a gun was a tool much like a shovel. According to historian Pamela Haag, "in the key years of its diffusion, and for many years thereafter, it was like a buckle or a pin, an unexceptional object of commerce." Today Oliver Winchester is a legendary name in the firearms industry, his namesake company having celebrated its $150^{\text {th }}$ anniversary in 2016. But in Haag's account, Winchester "went into the gun business the way his compatriots went into corsets or hammers." She continues, "In the Winchester company's early ads, the gun comes across as closer to a plow than a culturally charged object, more on the tool side of the equation than the totem side."3

Over time, the uses and meanings of guns have changed; which is to say, gun culture has changed. "What began as a necessity of agriculture and the frontier," Hofstadter observes, "took hold as a sport and as an ingredient in the American imagination." Fraternal shooting clubs in major American cities like New York, Cincinnati, Milwaukee, and San Francisco predated the National Rifle Association's founding and promotion of long-range shooting competitions. ${ }^{4}$ Hunting became not only a source of food but a dominant form of recreation for many. ${ }^{5}$ Receiving a "real"

\footnotetext{
${ }^{3}$ Haag, Pamela, The Gunning of America: Business and the Making of American Gun Culture (New York: Basic Books, 2016), p. xii, xiv, xvii.

${ }^{4}$ Gilmore, Russell S. 1999. “'Another Branch of Manly Sport': American Rifle Games, 1840-1900.” In J.E. Dizard, R.M. Muth, and S.P. Andrews, Jr. (Eds.), Guns in America: A Reader. (pp. 105-21). New York: NYU Press. Hummel, Richard. 1985. "Anatomy of a Wargame: Target Shooting in Three Cultures." Journal of Sport Behavior 8 (3): 131-43.

${ }^{5}$ Marks, Stuart A. 1991. Southern Hunting in Black and White: Nature, History, and Ritual in a Carolina Community. Princeton, NJ: Princeton University Press.
} 
rifle came to be a rite of passage from boyhood into manhood. ${ }^{6}$ And the attachment to guns was soon routinely expressed in popular culture, from Ernest Hemingway's novels to "High Noon" with Gary Cooper and Grace Kelly.

These examples highlight the diversity of American gun culture. Indeed, some go as far as to say that there is no such thing as gun culture (in the singular), but only gun cultures (plural). In her important book, Shooters: Myths and Realities of America's Gun Cultures, Abigail Kohn defines a gun culture as "one that uses a common language about guns and shares a set of signs and symbols pertaining to guns in everyday life."7 Kohn observes several such cultures just in the San Francisco Bay Area in the late $20^{\text {th }}$ century: those who own guns because they like them and enjoy shooting them for sport, those who hunt, and those who have them for self and home defense. Among the sport shooters are a subgroup who are very involved in an organization called the Single Action Shooting Society (SASS). SASS sponsors "cowboy action shooting" matches which draw heavily on realities and myths of frontier life in the $19^{\text {th }}$ century. The participants dress in period garb (Old West or Victorian) and shoot courses of fire using the kinds of firearms available at the time: single-action revolvers, pistol caliber leveraction rifles, and side-by-side (double-barreled) shot guns.

\footnotetext{
${ }^{6}$ Littlefield, Jon, and Julie L. Ozanne, "Socialization into Consumer Culture: Hunters Learning to be Men." Consumption Markets \& Culture 14:4 (December 2011):333-360.

7 Abigail A. Kohn. 2004. Shooters: Myths and Realities of America's Gun Cultures (New York: Oxford University Press), p. 4.
} 
These diverse gun subcultures in America notwithstanding, this chapter takes up the questions of whether there is a core or center of gravity of gun culture, what constitutes the core, whether it has shifted over time, and if so, when that shift took place. We hypothesize that there is indeed a center of gravity in U.S. gun culture, and that it has evolved over time from Gun Culture 1.0, the historic gun culture that Hofstadter described, to Gun Culture 2.0, America's contemporary gun culture. There are a number of differences between Gun Culture 1.0 and Gun Culture 2.0, but most significantly, Gun Culture 1.0 was grounded in sport shooting and hunting, and Gun Culture 2.0 is centered on personal/family/home defense and concealed carry. ${ }^{8}$

We test our hypothesis using data drawn from gun advertising. Although not a perfect representation of gun culture, using advertising as one measure of culture has some distinct benefits. In The Gunning of America, Haag argues that the gun industry companies like Winchester and Remington - manufactured not only firearms but made American gun culture itself. Although this goes too far in our view, it does highlight the fact that, as with many cultures, gun culture has a material dimension based in humanly fabricated products and these products circulate as commodities in the consumer marketplace. A major way in which people participate in gun culture is through consumption of these products. Understanding the production and

\footnotetext{
8 See David Yamane's review essay, "The Sociology of U.S. Gun Culture," Sociology Compass 11:7 (July 2017), doi:10.1111/soc4.12497.
} 
distribution of this material culture requires examining what the sociologist of culture Wendy Griswold calls the "complex apparatus which is interposed between cultural creators and consumers." According to Griswold, "This apparatus includes facilities for production and distribution; marketing techniques such as advertising, co-opting mass media, or targeting; and the creation of situations that bring potential cultural consumers in contact with cultural objects." ${ }^{\prime 9}$ Of the various aspects of the cultural apparatus Griswold highlights, advertising provides one of the most consistent sources of data over a long period of time. Her overreach on business and the making of American gun culture notwithstanding, Haag is exactly correct in observing the parallel between the rise of consumer capitalism in the $20^{\text {th }}$ century and the gun industry's embrace of mass advertising. In the marketplace of commodities, "the gun was no exception to the business trends of the day in a new consumer culture, whether the product was soap or a rifle."10

We are not the first to conduct content analysis of gun magazines or advertising in gun-related magazines. Philip Lamy analyzed eight years of Soldier of Fortune magazine (1983-1990) to document the presence of apocalyptic millennialism in the text, and Elizabeth Hirschman examined the expression of the core American value of

\footnotetext{
${ }^{9}$ Griswold, Wendy, Cultures and Societies in a Changing World, $4^{\text {th }}$ edition (Los Angeles: Sage, 2012), p. 73.

${ }^{10} \mathrm{Haag}$, Pamela, The Gunning of America: Business and the Making of American Gun Culture (New York: Basic Books, 2016), p. xviii. See also Lears, Jackson. Fables Of Abundance: A Cultural History Of Advertising In America (New York: Basic Books, 1995). Marchand, Roland. Advertising the American Dream: Making Way for Modernity, 1920-1940 (Berkeley: University of California Press, 1986).
} 
rugged individualism in the editorial content and advertising in nine different magazines for one year, including Guns \& Ammo and Rifleshooter. ${ }^{11}$ Although interesting, these studies examine how wider cultural values and beliefs get expressed in gun magazines as opposed to what themes are internal to gun culture itself. James Jacobs and Domingo Villaronga begin to fill this gap by providing a "map" of American gun culture by examining the overall focus, editorial content, and advertising for 77 different gun magazines they identified in 2001 and 2002. Broadly speaking, they identify $39 \%$ of magazines as focusing on hunting, $18 \%$ on sport shooting, and $8 \%$ on military and law enforcement. $9 \%$ are trade publications and $26 \%$ are what they called general interest magazines, like The American Rifleman and Guns \& Ammo. ${ }^{12}$ Although the most comprehensive in terms of the number and different types of magazines covered, Jacobs and Villaronga's study is cross-sectional and gives equal weight to

\footnotetext{
${ }^{11}$ Lamy, Philip. "Millennialism in the Mass Media: The Case of 'Soldier of Fortune' Magazine." Journal for the Scientific Study of Religion 31, no. 4 (December 1, 1992): 408-24. doi:10.2307/1386853; Hirschman, Elizabeth C. "Men, Dogs, Guns, and Cars: The Semiotics of Rugged Individualism." Journal of Advertising 32, no. 1 (April 1, 2003): 9-22. Although not a content analysis, Blair and Hyatt conducted an experimental study to examine whether exposure to gun advertising affects gun-related attitudes. Blair, M. Elizabeth, and Eva M. Hyatt. "The Marketing of Guns to Women: Factors Influencing Gun-Related Attitudes and Gun Ownership by Women." Journal of Public Policy \& Marketing 14, no. 1 (April 1, 1995): 117-27.

12 Jacobs, James B., and Domingo Villaronga. "Mapping the U.S. Gun Culture: A Content Analysis of Gun Magazines." Journal on Firearms and Public Policy 16 (2004): 135. There are also some errors in the article which cast some doubt on its findings. Although they claim in the text to have identified 84 U.S. gun magazines (p. 136), the Appendix lists only 77 (pp. 151-53). Also, in the text they claim there are 16 sport shooting magazines, including Shooting Times, but in the Appendix they list only 14 sport shooting magazines not including Shooting Times, which is instead listed under the Trade category. In fact, Shooting Times is a general interest gun magazine. Also, the December 2001 issue of Concealed Carry Handguns magazine is quoted in the text under the "General Interest" category (p. 146) but is not included in any of the categories in the Appendix.
} 
magazines with vastly different levels of circulation, creating a static and distorted map of gun culture.

The article that most directly inspired the research presented in this chapter examined firearms advertisements in all 27 currently publishing, ad-accepting magazines listed in the "guns and shooting" category in the 2002 edition of Bacon's Magazine Directory. Elizabeth Saylor, Katherine Vittes, and Susan Sorenson identified all advertisements by firearms manufacturers for guns in a single 2002 issue of each of the 27 magazines and used a systematic content analysis coding protocol to identify the themes depicted in those advertisements. Considering just the dominant overall theme in each ad, the most common attributes of firearms used to sell the products were "attributes of the gun" (38.1\%), "hunting/outdoors" (20.4\%), "patriotism" (15.0\%), and "combat/military" (7.1\%). "Self-protection" $(2.7 \%)$ is the $11^{\text {th }}$ most common theme of 14 themes coded. ${ }^{13}$ Despite its virtues, this article misrepresents the core of American gun culture by giving equal weight to the advertisements in magazines such as Accurate Rifle (circulation in 2001 of 8,000), Shotgun Sports (circulation 15,500), Guns \& Ammo (circulation 607,971) and The American Rifleman (circulation 1,366,073). Like Jacobs and Villaronga's work, Saylor, Vittes, and Sorenson also cannot speak to changes in gun advertising over time.

\footnotetext{
${ }^{13}$ Saylor, Elizabeth A, Katherine A Vittes, and Susan B Sorenson. "Firearm Advertising: Product Depiction in Consumer Gun Magazines." Evaluation Review 28, no. 5 (October 2004): 420-33. doi:10.1177/0193841X04267389.
} 
We go beyond these other more empirically limited studies by systematically analyzing the content of gun advertising in The American Rifleman magazine over the past century, from 1918 to 2017. In the following section we describe at some length our data and methods.

\section{Data and Methods}

This study analyzes advertising in the oldest and largest circulation general interest gun magazine in the United States: The American Rifleman. The magazine has been continuously published since 1885, as The Rifle until 1888, Shooting and Fishing to 1906, and Arms and the Man to 1923. In 1916, then-owner and former National Rifle Association president James A. Drain sold Arms and the Man to the NRA for \$1. It has been published by the NRA since then, and given as a membership benefit since the 1920s, driving its circulation ever upward..$^{14}$

Among those magazines that submit to the audits by the Alliance for Audited media, The American Rifleman's circulation of 2,056,368 ranks first in the "Fishing \& Hunting" category, doubling the circulation of the popular outdoor magazine Field $\mathcal{E}$

\footnotetext{
${ }^{14}$ David T. Hardy, "American Rifleman," in Guns in American Society : An Encyclopedia of History, Politics, Culture, and the Law, $2^{\text {nd }}$ edition, edited by Gregg Lee Carter (Santa Barbara, CA: ABC-CLIO, 2012); James E. Serven, Americans and Their Guns (Harrisburg, PA: Stackpole Books, 1967). Today, NRA members can opt to receive American Hunter (published since 1973, current circulation 931,314) or America's First Freedom (published since the 1990s, current circulation 651,966) instead of The American Rifleman. See also Tiia Rajala, "Gun Magazines." Pp. 351-54 in Guns in American Society: An Encyclopedia of History, Politics, Culture, and the Law, Volume 2, 2nd edition. Edited by Greg Lee Carter (Santa Barbara, CA: ABC-CLIO, 2012).
} 
Stream $(1,005,811)$ and dwarfing the next highest circulation general interest gun magazine, Guns $\mathcal{E}$ Ammo $(377,584)$. Considering consumer magazines as a whole, The American Rifleman has a smaller circulation than Sports Illustrated $(2,759,243)$ and ESPN The Magazine $(2,137,290)$ but a larger circulation than Golf $(1,412,093)$ or Car and Driver $(1,207,714) \cdot{ }^{15}$ Because of its official journal status and broad audience, The American Rifleman must be the most inclusive of all aspects of gun culture in its editorial content and advertising. Therefore, analyzing the content of advertising in this magazine provides a conservative test of our hypothesis about changes in American gun culture overall. ${ }^{16}$

\section{Sampling}

The sample of advertisements analyzed in this study comes from a single randomly selected issue of The American Rifleman for each of the 100 years from 1918 through 2017. We used a random number generator set from 1 (January) to 12 (December) to determine which of the 12 monthly issues to examine for each year. We then acquired the specified issues either from the first author's collection (for more recent issues) or purchased them through eBay (for older issues).

\footnotetext{
${ }^{15}$ Circulation data is the Alliance for Audited Media average for the six months ended 30 June 2017. ${ }_{16}$ Preliminary results of an ongoing analysis of Guns magazine show the same trends as this study, but more pronounced.
} 
To be included in the sample, an advertisement had to meet three main criteria. First, the ad had to be at least one-quarter of a page in size. Second, the ad had to be placed by the manufacturer, licensed dealer, or importer of the product (e.g., Firearms International Corporation, Remington, Charter Arms). Ads placed by comprehensive sporting goods stores (e.g., Gander Mountain, Warhsal's Sporting Goods, Hudson Sporting Goods) or gun stores (Midway USA, Brownell's, United Arms Company) were not coded unless the store was selling their own brand of product. Third, the ad had to be for firearms (handguns, rifles, shotguns, or a variety of gun types), ammunition (but not separate parts of ammunition or reloading equipment), gun accessories (products designed to be attached to or affect the utility of a firearm in some way), or some combination of these products. As described in this chapter's introduction, firearms themselves are just one of many commodities circulating within gun culture. ${ }^{17}$ These inclusion criteria resulted in a total of 1,708 advertisements from 100 issues of The American Rifleman.

\footnotetext{
${ }_{17}$ Without ammunition, for example, a gun is just a paperweight. And the increasing number of advertisements for holsters is among the strongest indicators of the increasing centrality of self-defense in gun culture. See David Yamane, "'The First Rule of Gunfighting is Have a Gun': Technologies of Concealed Carry in Gun Culture 2.0," in The Social Life of Guns (New York: Oxford University Press, forthcoming).
} 


\section{Coding}

Adapting the work of Saylor, Vittes, and Sorenson, our content analysis began with 9 themes: technical superiority, hunting, collecting, military, law enforcement, sport/recreation, tactical, personal protection/self-defense/home or family defense, and concealed carry. After dropping advertisements that had none of these nine themes, we were left with 1,456 advertisements.

Because our interest in this chapter is in examining the shift from Gun Culture 1.0 to Gun Culture 2.0, we focus here on just four of these themes, described in Table 1. Of these four themes, hunting and sport shooting are reflective of the older Gun Culture 1.0, and personal protection/self-defense/home/family defense and concealed carry are reflective of the newer Gun Culture 2.0.

\section{Table 1. Gun Magazine Advertisement Coding Scheme}

\begin{tabular}{|l|l|}
\hline CODE & CODE DEFINITION \\
\hline Hunting & $\begin{array}{l}\text { Product is associated with hunting, through images (e.g., owner in } \\
\text { hunting-related camo, animals in cross hairs) or text (e.g., "small game") }\end{array}$ \\
\hline Sport/Recreation & $\begin{array}{l}\text { Product is promoted for informal recreational shooting (except hunting), } \\
\text { or linked to any of the various shooting sports, precision rifle, clay target } \\
\text { shooting, action shooting sports (3-gun, USPSA, IPSC, IDPA), Olympic }\end{array}$ \\
\hline
\end{tabular}




\begin{tabular}{|c|c|}
\hline CODE & CODE DEFINITION \\
\hline & $\begin{array}{l}\text { shooting, etc., through images (e.g., a shot timer, clay pigeons, ) or text } \\
\text { (e.g., "competition," "plinking"). }\end{array}$ \\
\hline Personal & Product is portrayed as an effective and/or important means of home, \\
\hline Protection/Self- & family, and/or personal or self-protection, through images (e.g., \\
\hline Defense/Home & confronting an assailant in a parking lot or alley, hiding behind bed with \\
\hline or Family & gun) or text (e.g., "engineered to defend," "comfort runs in our family, so \\
\hline Defense & you can protect yours"). \\
\hline Concealed Carry & $\begin{array}{l}\text { Product is portrayed as designed to facilitate the carrying of a concealed } \\
\text { firearm, through images (e.g., an inside the waistband holster) or text } \\
\text { (e.g., "IWB," "carry more comfortably"). }\end{array}$ \\
\hline
\end{tabular}

Unlike Saylor, Vittes, and Sorenson who coded the "main" theme of an advertisement, we coded all themes present in each advertisement as many reflected multiple themes. Hunting and sport shooting are often found together, though are not identical. Likewise, many products coded for concealed carry are also coded for personal protection/self-defense, but they too are distinct categories.

Extensive tests were undertaken to ensure that researchers applied the coding scheme identically. Krippendorf's $\alpha$ (alpha) was used to assess inter-coder reliability. According to Krippendorf, it is customary to require $\alpha \geq .800$ to conclude that the 
coding scheme and instructions are reliable. ${ }^{18}$ By the fourth round of coding, each specific attribute coded had Krippendorf's $\alpha>0.80$, and all attributes collectively had $\alpha$ $=0.87$. At that point, trained researchers coded advertisements independently, with the lead investigator spot-checking the results.

\section{Analysis}

On average there are more advertisements in The American Rifleman over the century covered in this analysis; therefore, we normalize our results for each individual year. Rather than giving each advertisement equal weight and calculating the percentage of advertisements in each issue that reflect a particular theme, we normalize the advertising content by looking at the proportion of all advertising space as the denominator. We do this by recording and adding together the size of each ad that meets our selection criteria for each issue (two, full, half, third, or quarter page). The total coded advertising space ranges from 2.0 pages in February 1918 to 26.82 pages in

October 2017. (The general trend is upward, but there are anomalies along the way, like the 22.16 pages of advertising coded in October 1936 and 4.33 pages in May 1999.)

\footnotetext{
${ }^{18}$ Krippendorff, Klaus, Content Analysis: An Introduction to Its Methodology, $3^{\text {rd }}$ edition (Thousand Oaks, CA: Sage, 2013). We used the free reliability calculator, ReCal3: Reliability for 3+ Coders, on Deen Freelon's web page: http://dfreelon.org/utils/recalfront/recal3/. See our work-in-progress, "Targeted Advertising: Documenting the Emergence of America's New Gun Culture in Guns Magazine," for more details on the tests for inter-coder reliability.
} 
We then multiply the presence of each coding theme in each advertisement by the size of the ad. For example, a half page ad for a hunting rifle is 0.5 , a one-third page ad for a concealed carry holster is 0.33 , and so on. Combing those products for each advertisement in each issue then dividing them by the total coded advertising space produces the percentage of total advertising space with that particular attribute. For example, 2.5 advertising pages in the October 1920 issue included hunting as a theme, out of 5.0 total advertising pages coded in that issue. So, $50 \%$ of all advertising space in that issue of The American Rifleman included hunting as a theme. By contrast, 9.25 advertising pages in the October 2010 issue had the hunting theme, out of 28.08 total coded advertising pages, for a 33\% proportion of all advertising pace in that issue.

This procedure not only controls for the increasing number of advertisements over time, but also captures the reality that a full-page advertisement matters more than a half-, third-, or quarter-page advertisement.

\section{Results}

Examining Gun Culture 1.0 themes of hunting and sport/recreational shooting first, we see that these themes are present throughout the 100 years of advertising in The American Rifleman we analyzed. However, the relative proportion of all advertising space coded that reflected these themes declined by 2017. The two themes did show different patterns over the century examined. The red trend line in Figure 1 shows the 
pattern for hunting. Hunting as a theme in gun advertising increased through the 1960s, and only then began to decline, quite precipitously over the past decade.

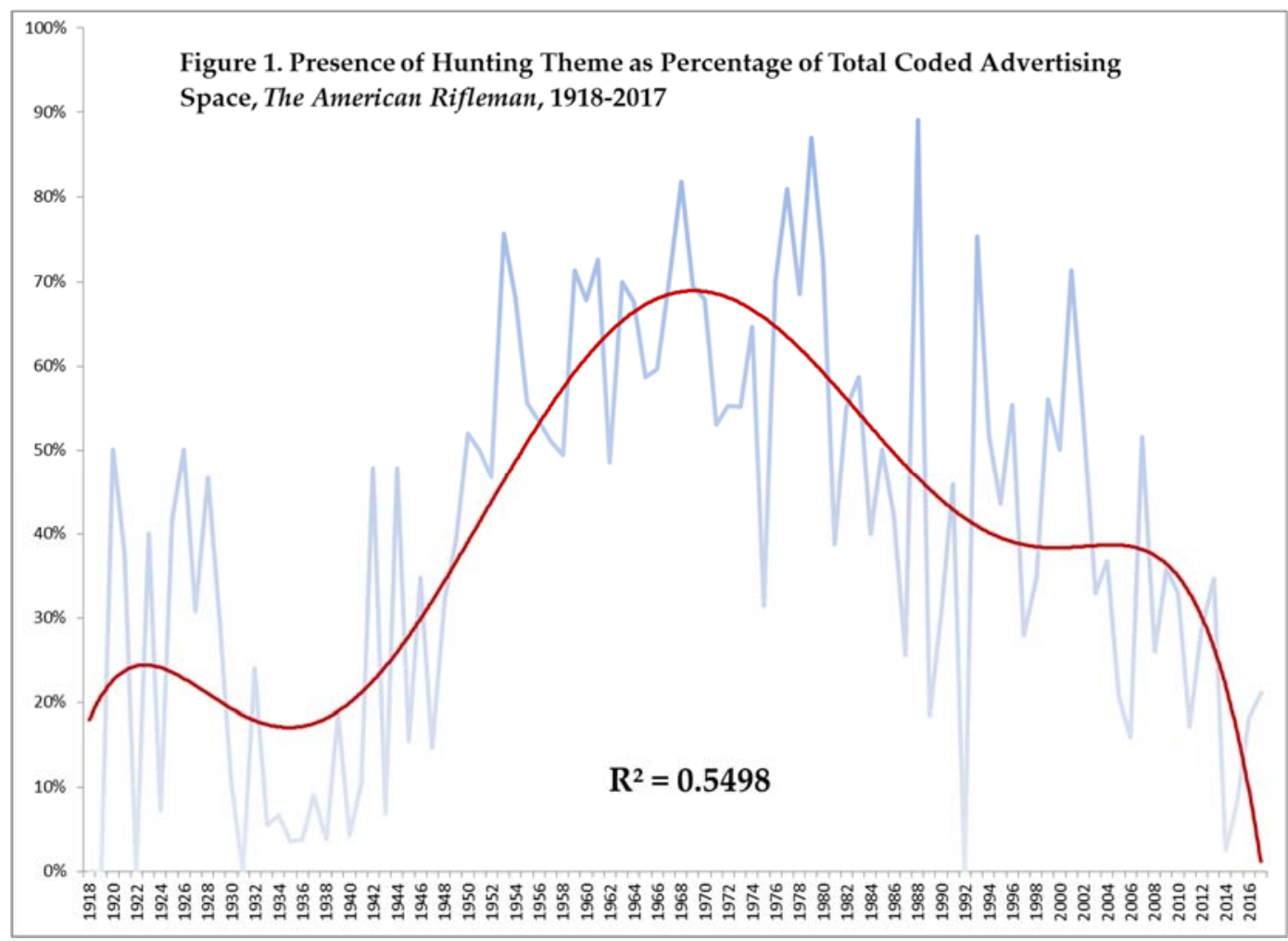

In Figure 2, we see a different pattern initially for the sport and recreational shooting theme compared to the hunting theme, with advertisements drawing on this theme declining steadily through the period studied. The contrast is especially evident in the middle decades of the $20^{\text {th }}$ century (1948-1968) when hunting was peaking as an advertising theme. That said, for both hunting and sport/recreational shooting, the overall pattern from the 1970s forward is one of decline. 


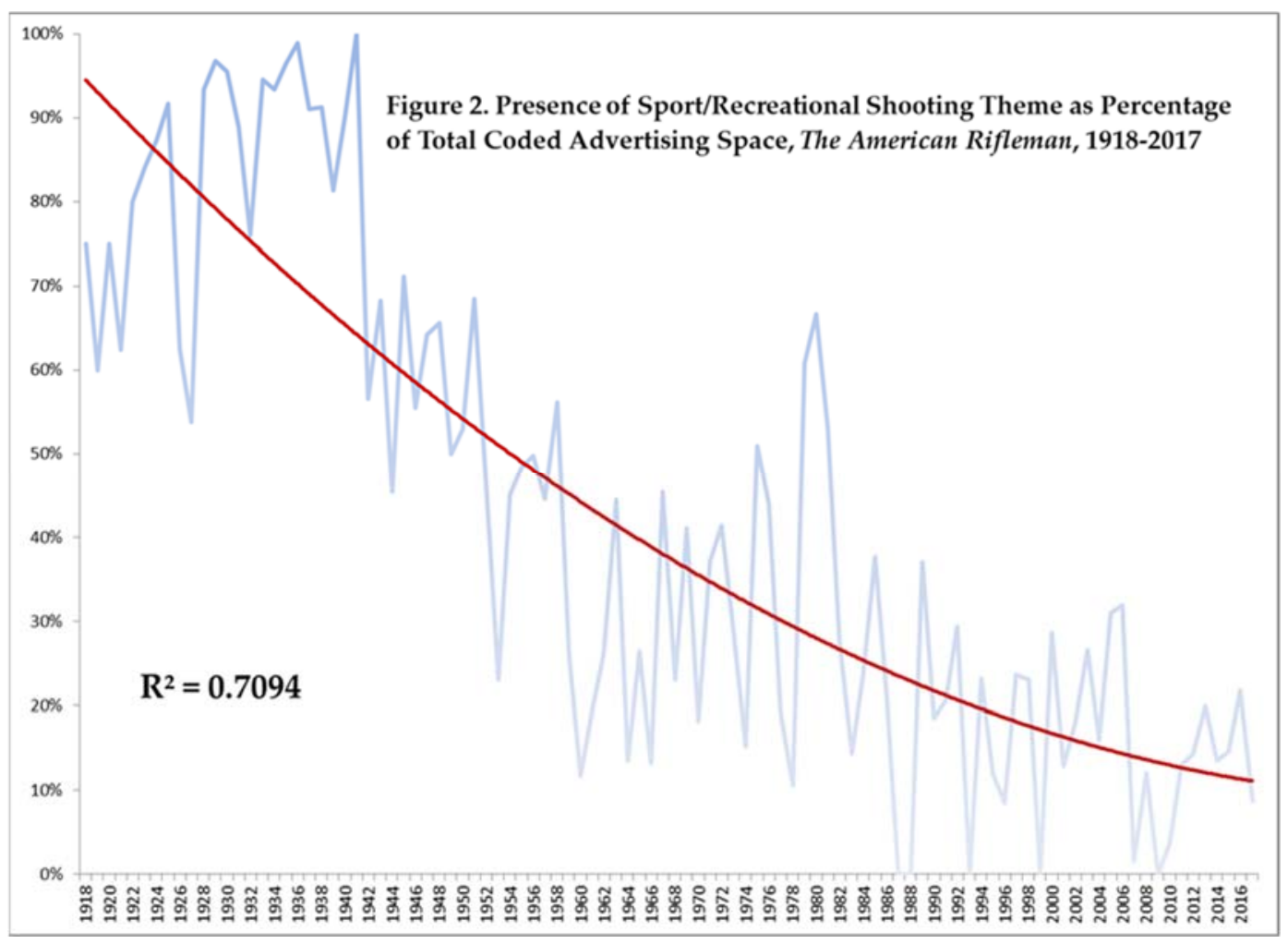

As noted in the introduction, home defense was a theme in some gun advertising even in 1918. But ads drawing on any of the themes in the broad category of personal protection/self-/home or family defense were exceptional for most of the $20^{\text {th }}$ century. As shown in Figure 3, Gun Culture 2.0 began to gain strength in the 1970s, indicated by the green trendline for personal protection/defense edging upward from that point forward. 


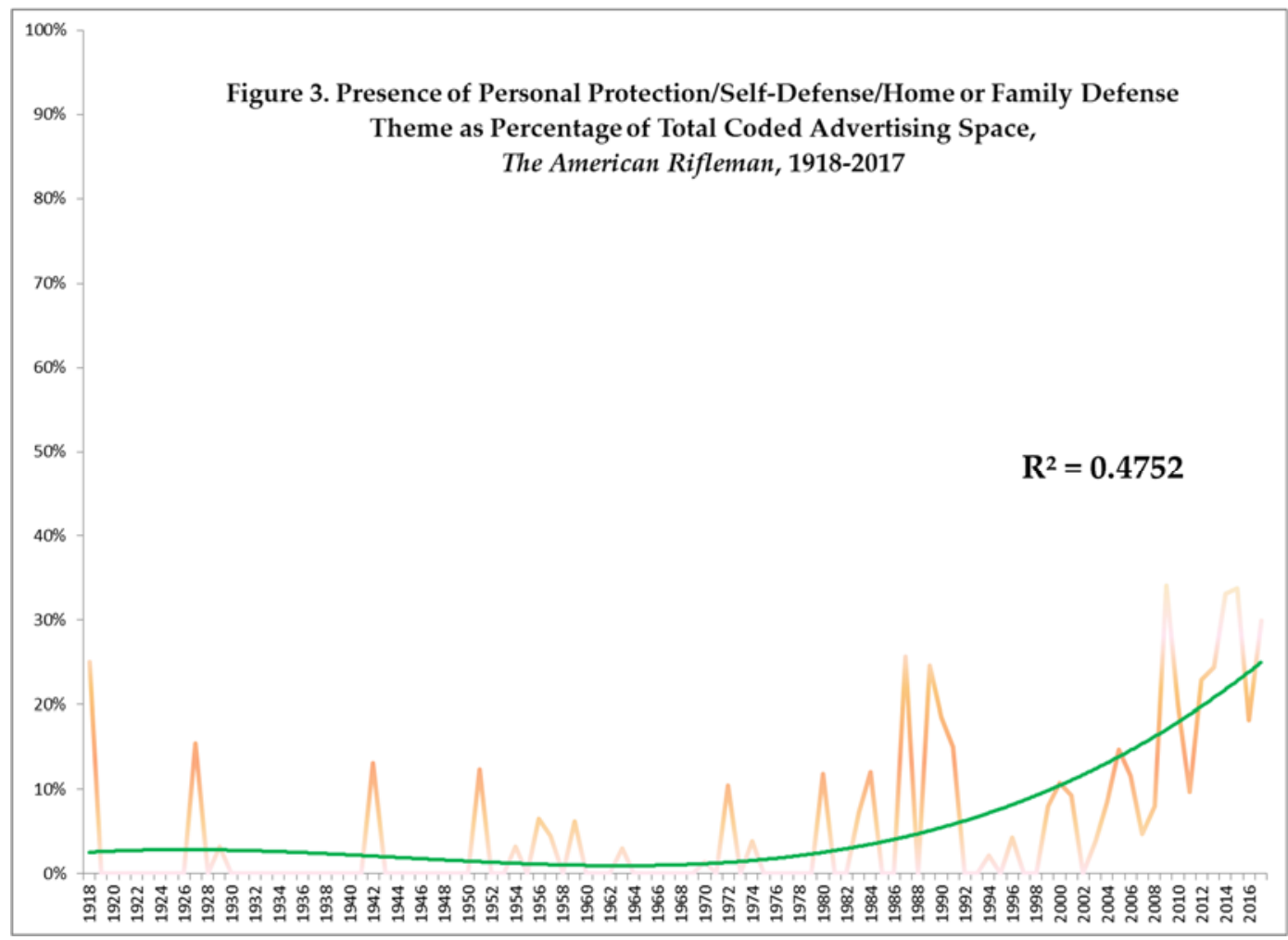

Figure 4 examines the trend in advertising drawing on the concealed carry theme and finds a pattern similar to that of personal protection/defense, but with a delayed onset and steeper increase in the trend. Note that both personal protection/defense and concealed carry show some spikes in the mid-to-late-1980s, which is recognized as the beginning of the shall-issue concealed carry revolution in the United States. ${ }^{19}$

19 Patrick, Brian Anse. Rise of the Anti-Media: In-Forming America's Concealed Weapon Carry Movement (Lanham, MD: Lexington Books, 2009). 


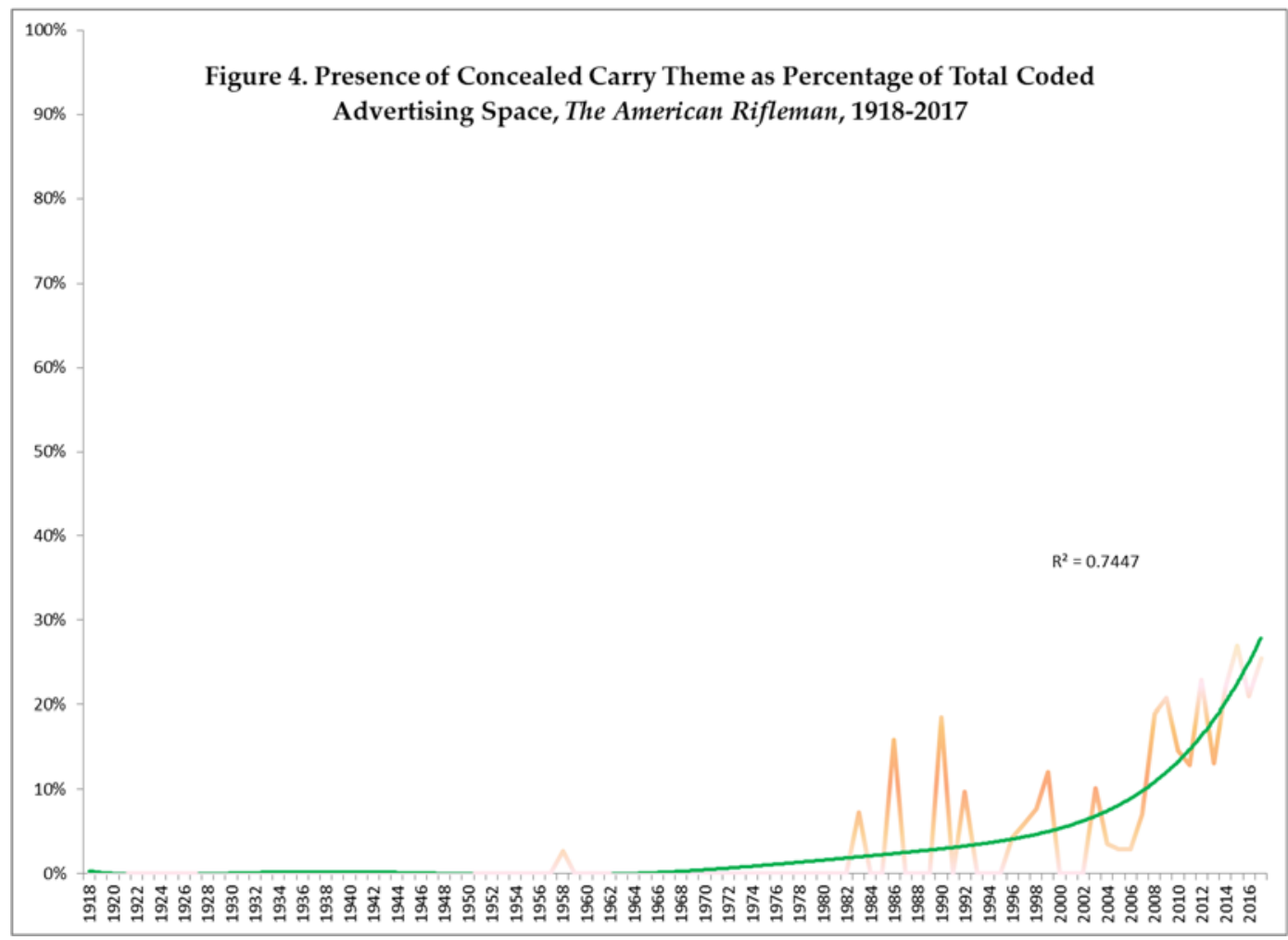

To return to the questions posed at the outset, then, has the core of American gun culture shifted from hunting and sport shooting to personal protection/self-/home and family defense and concealed carry? As measured through gun advertising, it is safe to conclude yes. Gun Culture 1.0 themes are found in a declining proportion of advertisements in The American Rifleman over the past 100 years, and Gun Culture 2.0 themes are increasing.

Although their trajectories are converging, have Gun Culture 2.0 themes overtaken Gun Culture 1.0 themes in advertising? To begin to answer this question, we combined the proportion of ads with the hunting and sport/recreational shooting themes, and the proportion of ads with the personal protection/self-/home and family 
defense and concealed carry themes, and plotted those two trends together on the same graph. Figure 5 shows the convergence of the trend lines for these two themes from the 1970s forward, their meeting in 2014, and divergence thereafter, with Gun Culture 2.0 themes superseding Gun Culture 1.0 themes. Looking at the underlying data, in 2014, $45.3 \%$ of all advertising space coded reflected Gun Culture 2.0 themes while only $15.9 \%$ reflected Gun Culture 1.0 themes. Although hunting and sport/recreational shooting themes rebounded to $28.6 \%$ of all advertising space in 2017, personal protection/defense and concealed carry remained higher, with $46 \%$ of all advertising space reflecting these themes.

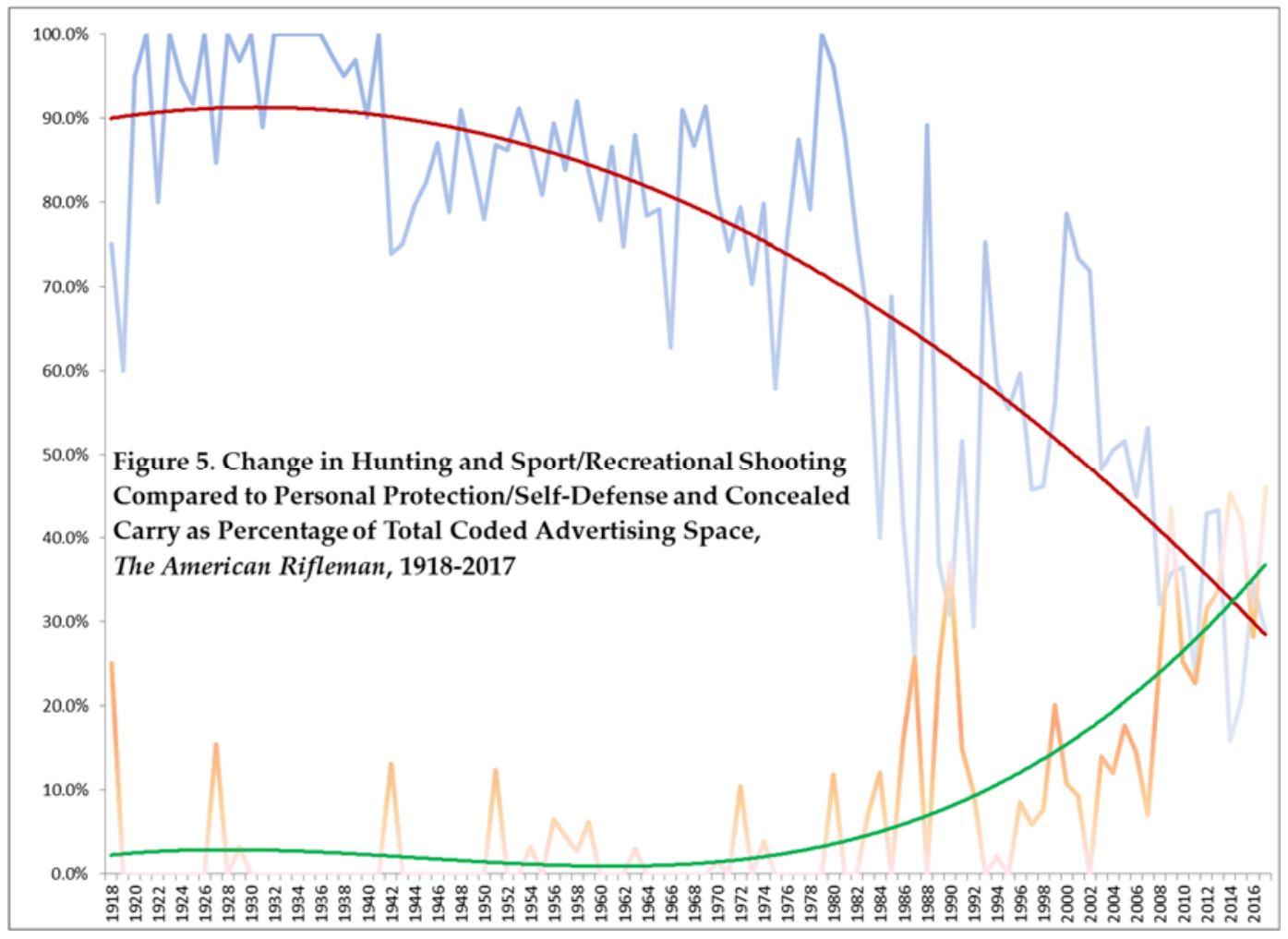




\section{Conclusion}

This systematic content analysis of gun advertising in Arms and the Man/The American Rifleman shows that the predominance of Gun Culture 1.0 themes persists through the 1970s and into the 1980s, when the center of gravity of gun culture begins to shift decisively toward the Gun Culture 2.0 themes of personal protection/defense and concealed carry. This trend continues through the 1990s and 2000s, with the two emphases crossing-over in just the past few years. Gun Culture 2.0 is now America's dominant and still expanding core gun culture today.

It is also important to note that in distinguishing between Gun Culture 1.0 and Gun Culture 2.0, we are drawing on the language of "versions" or "generations" of the World Wide Web shifting from Web 1.0 to Web 2.0 (and beyond). Just as Web 2.0 grew out of but did not simply replace Web 1.0, Gun Culture 2.0 developed out of and added new elements to the Gun Culture 1.0. Recognizing the centrality of the culture of armed defense to Gun Culture 2.0 does not mean that self-defense was not a part of gun culture previously. Similarly, older core elements of Gun Culture 1.0 like hunting and target shooting survive, but are less central to gun culture in general.

Some individuals who were raised in Gun Culture 1.0 became leading figures in the development of Gun Culture 2.0, while others only partially transitioned. Those who have begun to move out of the historic gun culture but have not yet firmly settled 
into the contemporary gun culture can be thought of as Gun Culture Version 1.2, 1.6, etc., depending on how far they have transitioned. And, of course, there are some who have remained steadfastly at home in Gun Culture 1.0. The newer gun culture even has a name for these throwbacks to the old gun culture: "Fudds," after the Looney Tunes cartoon character Elmer Fudd, the hapless hunter who can never bag his prey, Bugs Bunny. Highlighting the dynamism of gun culture, efforts are being made to combine the historic interest in shooting sports with the contemporary interest in personal protection and concealed carry in competitions sponsored by organizations like the International Defensive Pistol Association (IDPA). In IDPA events, competitors shoot courses of fire designed to replicate possible defensive shooting situations, like home invasions or parking lot robberies.

A quantitative content analysis of advertising in one gun magazine of course has its limits. More subtle, qualitative analyses of these changing themes would add flesh to the skeleton of trend data we have constructed here. Furthermore, being a part of gun culture is not simply about holding a particular set of beliefs. According to Stebbins, “Serious leisure participants typically become members of a vast social world, a complex mosaic of groups, events, networks, organizations, and social relationships." The same is true for participants in both recreational and self-defense gun culture. America is not just a "Gun Show Nation," to use Burbick's famous phrase, it is a nation of gun clubs, training classes, shooting events, network meet-ups, gun collectors and 
shooters associations. ${ }^{20}$ Kohn approaches gun culture this way in Shooters, but more solidly ethnographic work like hers is necessary. Going forward, further attention should be paid especially to the social organization of armed citizenship and concealed carry, building on Jennifer Carlson's fine work, as well as the complex personal dynamics of becoming a gun carrier, following in Angela Stroud's and Harel Shapira's footsteps. ${ }^{21}$

As Yamane has argued, American gun culture is shaped by social institutions including the legal system, economy, and technology, and these requires greater attention as well. ${ }^{22}$ In the larger project of which this chapter is a part, Yamane applies this perspective to Gun Culture 2.0. For example, the widespread practice of legally carrying a gun in public was facilitated by the movement for shall issue concealed carry laws. The growing practice of concealed carry that is facilitated by these laws also creates a number of new challenges for the individuals who do so, as well as for the broader social worlds (other people, spaces, places) in which they do so. These challenges are individually and collectively addressed through the developing culture

\footnotetext{
${ }^{20}$ R.A. Stebbins, "Serious Leisure," Society 38:4 (2001), p. 54, and Joan Burbick, Gun Show Nation: Gun Culture and American Democracy (New York: New Press, 2007). See David Yamane, "What's Next? Understanding and Misunderstanding America's Gun Culture," in Craig Hovey and Lisa Fischer, eds., Understanding America's Gun Culture (Lanham, MD: Lexington Books, 2017).

${ }^{21}$ Angela Stroud, Good Guys with Guns: The Appeal and Consequences of Concealed Carry (Chapel Hill: University of North Carolina Press, 2016), and Harel Shapira and Samantha Jones Simon, "It's Just a Tool: How Gun Owners Justify Carrying their Guns," paper presented at the annual meeting of the American Sociological Association, Montreal, Quebec, Canada, August 2017.

${ }^{22}$ David Yamane, “The Sociology of U.S. Gun Culture," Sociology Compass 11:7 (July 2017), doi:10.1111/soc4.12497.
} 
of armed citizenship - both the "hardware" of material culture like guns, accessories, and other products, as well as the "software" of ways of thinking, legal frameworks, and the development of relevant abilities. None of these aspects of Gun Culture 2.0 have been adequately studied to date. 